\title{
Why Government Institutions in Developing Countries Cannot Account for Public Funds: Empirical Evidence from Cross River State of Nigeria
}

\author{
William Smart Inyang \\ Department of Accounting, University of Calabar, Nigeria
}

Copyright $(2016$ by authors, all rights reserved. Authors agree that this article remains permanently open access under the terms of the Creative Commons Attribution License 4.0 International License

\begin{abstract}
The study investigated why MDAs in African countries cannot account for public funds. A 5-point likert scale questionnaire was used to collect primary data from 62 staff members of State and Local government auditor-general's offices who participated in the study. Five hypotheses were formulated and tested for the study using multiple regression. The study attributed the occurrence of unretired imprests in Cross River State MDAs to the following factors: lack of budgetary provisions, fraudulent delegation of imprest retirement and improper reimbursement of imprests and it was further revealed that off-budget expenditures and non-retirement of imprests by other heads of departments have little or no association with unretired imprests. The study therefore, recommended that overhead cost budgets of the MDAs be constantly revised and appropriate sanctions be levelled against MDA officials who engage in fraudulent delegation of accountability over the imprest funds and improper reimbursement of imprests.
\end{abstract}

Keywords Unretired Imprests, Budgetary Provisions, Off-budget Expenditures, Retirement of Imprest, and Reimbursement of Imprest and Overhead Cost Budget

\section{Introduction}

Accountability over public funds is fundamental to the accounting profession and it has dominated financial accounting literature in recent times. This is the reason why Nigeria and developing African countries have designed and developed various accountability tools to effectively and efficiently manage their resources.

Unfortunately, and for no apparent reasons, unretired imprest funds (i.e. imprest funds not accounted for) have recently been reported in Tanzania, Zambia and Nigeria. Tanzania's unretired imprest of 3.1 trillion shillings (about $\$ 375.1$ billion) equals half of her national budget while
Zambia's Auditor-General recently reported the rampant abuse of Travel imprest worth billions of kwacha. This was further confirmed by Times of Zambia [29] which reported that the Public Accounts Committee (PAC) had expressed that all the Ministries could not retire imprests amounting to K445 billion. This consequently made the Zambian government to place a ban on foreign travel for public servants who could not retire the imprests they received to embark on official trips. Zambian public officers who could not retire their imprest funds within two weeks were therefore, to refund the unretired imprests from their salaries. $[29,28,14]$. In Nigeria where the current study was carried out, the Auditor-General of Cross River State reported that between 2009 and 2013, MDAs could not retire imprest worth over $¥ 1.7$ billion.[3-7]. Please see table 1 .

Past studies on financial accountability in MDAs investigated the causes of poor financial accountability without specifically examining the causes of unretired imprests (an enduring and well documented financial accountability problem). The purpose of the current study is therefore, to identify the reasons why unretired imprests frequently occur in African government MDAs using Cross River State of Nigeria as study area. What factors significantly contribute to the occurrence of unretired imprests in Nigeria's Cross River State MDAs? This is the question that the current study will attempt to answer.

\subsection{Objectives of the Study}

The main objective of this study is to identify the reasons why unretired imprests frequently occur in African government MDAs using Cross River State of Nigeria as the study area. The specific objectives to be achieved in this study are as follows:

1.1.1. To examine whether lack of budgetary provisions has any impact on the occurrence of unretired imprests in Cross River State MDAs.

1.1.2. To verify whether off-budget expenditures has any 
impact on the occurrence of unretired imprests in Cross River State MDAs.

1.1.3. To identify whether delegation of retirement of imprest has any impact on the occurrence of unretired imprests in Cross River State MDAs

1.1.4. To evaluate the impact of improper reimbursement on the occurrence of unretired imprests in Cross River State MDAs.

1.1.5. To assess the impact of non-retirement of imprest by other heads of departments on the occurrence of unretired imprests in Cross River State MDAs.

\subsection{Research Questions}

The current study will be guided by the following research questions:

1.2.1. To what extent has lack of budgetary provisions impacted on the occurrence of unretired imprests in Cross River State MDAs?

1.2.2. How dooff-budget expenditures affect the occurrence of unretired imprests in Cross River State MDAs?

1.2.3. Is the occurrence of unretired imprests in Cross River State MDAs affected by delegation of retirement of imprest?

1.2.4. How does improper reimbursement influence the occurrence of unretired imprests in Cross River State MDAs?

1.2.5. How does non-retirement of imprests by other heads of department affect the occurrence of unretired imprests in Cross River State MDAs?

\subsection{Research Hypotheses}

1.3.1. There is no significant relationship between lack of budgetary provisions and occurrence of unretired imprests in Cross River State MDAs.

1.3.2. There is no significant relationship between off-budget expenditures and occurrence of unretired imprests in Cross River State MDAs.

1.3.3. There is no significant relationship between delegation of retirement of imprest and occurrence of unretired imprests in Cross River State MDAs.

1.3.4. There is no significant relationship between improper reimbursement and occurrence of unretired imprests in Cross River State MDAs.

1.3.5. There is no significant relationship between non-retirement of imprests by other heads of departments and occurrence of unretired imprests in Cross River State MDAs.

\subsection{Scope of the Study}

This study will consider only the imprest expenditures incurred and not retired or accounted for by MDAs in Cross River State of Nigeria. The unretired imprest expenditures of organizations in the State's private sector and non-governmental organizations will not be included in the current study. Since unretired imprest funds adversely affect the smooth financing of recurrent expenses of government, the current study will therefore, be restricted to overhead cost budget which theoretically guides the rendition of government recurrent services.

\subsection{Justification of the Study}

This research is motivated by the rising occurrence of unretired imprests in Nigeria's Cross River State and some selected African countries' Ministries, Departments and Agencies (MDAs). Nigeria has a public sector that parades the largest labour force and bulkiest financial resources and she is ranked globally as the $6^{\text {th }}$ in oil and gas production but, lack of financial accountability has led to high level of poverty, poor infrastructures and ineffective public service delivery [24,2]. Mbaya and Namadi [20] discovered that mechanisms put in place so far in enforcing public accountability in the civil service have failed, resulting to poor spirit of accountability in the conduct of public affairs in Nigeria. Lack of accountability and transparency in the public sector is well known and fairly documented. Observations within the service and comments from World Bank, Transparency International etc, suggest that the problem is real and enduring [8]. This study will therefore, contribute to the extant literature by revealing how the incessant occurrence of unretired imprests can be prevented and minimized.

\subsection{Conceptual Framework}

Imprests are funds given to public officers to meet expenditures which are directly connected with the public service and which provisions for such expenditures exist in the estimates [9]. According to Adeshoba [1] imprest is a fixed amount given monthly to government MDAs to settle their recurrent expenses. Inyang [15] reported that the imprest expenditure is basically and conceptually a function of the overhead cost budget. Imprest funds are therefore, statutorily meant for procuring only the items of expenditure included in the approved overhead cost budgets of MDAs. Imprests must be retired or accounted for immediately after the purpose of the imprest has been accomplished. The retirement of imprest is usually done at the end of the

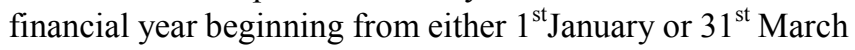
whichever, is statutorily stipulated [13]. Any recurrent expenditure from imprest which cannot be accounted for at the end of the stipulated date of accountability will therefore, be declared by the State Accountant-General as unretired or unaccounted for. Accounting for imprest expenditure simply involves the preparation of imprest payment vouchers and charging such vouchers to approved departmental votes or budgetary provisions and ensuring that retirement or accountability date is not exceeded. For the imprest expenditure to be properly accounted for, four basic 
conditions must be fulfilled as follows: authenticated payment vouchers must be raised for the imprest expenditure, approved departmental votes or budgetary provisions must be available with which to charge or support such an expenditure, date of accountability or retirement must not be exceeded and the documentation process leading to the retirement of the imprest or accountability must be accepted and approved by the State Accountant-General.

Consequently, six research variables were generated for the conceptual framework. These variables are: Occurrence of unretired imprests (dependent variable), Lack of budgetary provisions, Off-budget expenditures, delegation of retirement of imprest, improper reimbursement and Non-retirement of imprests by other heads of departments. (independent variables).

The interrelationships between the aforementioned variables are depicted in the schematic diagram (figure 1) below:

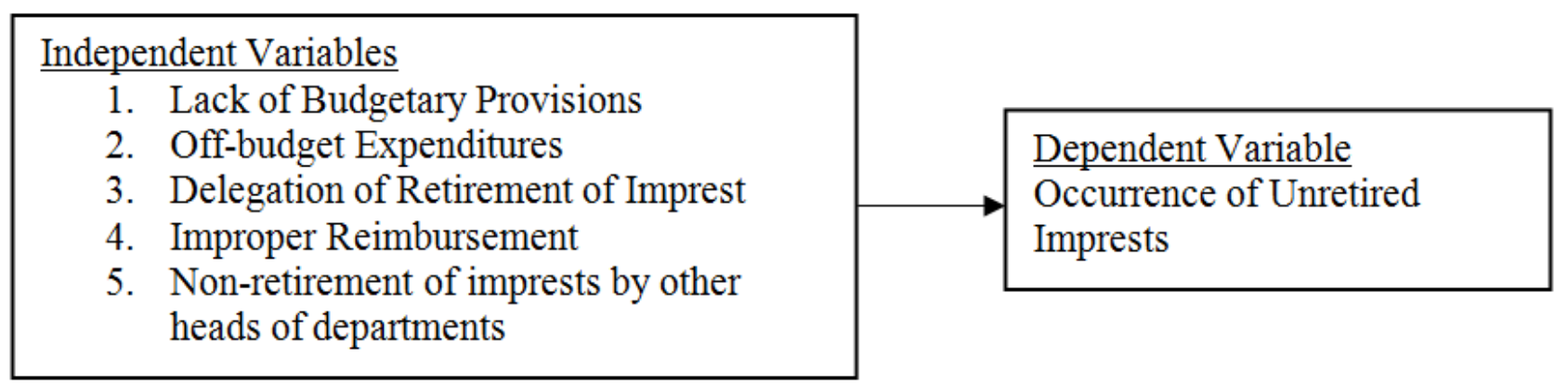

Figure 1. Conceptual Framework

The framework for the current study was anchored on the fact that unretired imprests will occur when the votes for the actual imprest expenditure incurred has been exhausted and when the actual imprest expenditure is not supported by the approved overhead cost budget. Delegating accountability to an officer who did not incur the imprest expenditure can lead to errors in the retirement process and this can make it difficult for the imprest to be accounted for and this may also cause the State Accountant-General not to accept the retirement of the said imprest. Furthermore, when fresh imprest fund is released even when the previous one has not been accounted for and when the imprests collected and spent by other heads of departments have not been retired or accounted for, unretired imprests will occur in a rising fashion. Therefore, the interrelationships which exist between these conceptual variables will be used to conduct the current study. 


\subsection{Operational Definition of Variables}

1.7.1. Occurrence of unretired imprests: This is the composite response scores of each respondent's extent of agreement that unretired imprests occur in Cross River State MDAs and appear annually in Cross River State Audit report.

1.7.2. Lack of budgetary provisions: This is represented by the composite response scores of each respondent's extent of agreement that MDAs' votes are exhausted before year end and are not replaced and accounted for.

1.7.3. Off-budget expenditures: This is the composite response scores of each respondent's extent of agreement that CRS MDAs sometimes incur unapproved expenditure and lack evidence of expenditure which make retirement of imprest difficult.

1.7.4. Delegation of imprest retirement: This is the composite response score of each respondent's extent of agreement that accountability over the imprest fund is delegated to an officer who did not incur the imprest expenditure and this delays the retirement of imprest.

1.7.5. Improper reimbursement: This is also represented by the composite response score of each respondent's extent of agreement that sometimes, emergency release of imprest to MDAs occurs and fresh imprest funds are released even when the previous one has not been accounted for.

1.7.6. Non-retirement of imprests by other heads of departments: This is the composite response score of each respondent's extent of agreement that all departmental heads use imprest and some of them delay retirement of imprests.

\section{Literature Review}

\subsection{Theories Justifying the Study}

\subsubsection{Agency Theory}

A relationship which exists between the principal and his agent is expressed in the agency theory. This type of relationship can be likened to that of owner and manager. The relevance of this theory to the current study lies in the relationship which exists between the Nigeria's Cross River State Government (Principal) and the Cross River State Ministries, Department and Agencies (Agent). The imprest fund is released by the NCRSG to the CRSMDAs according to an approved overhead cost budget and on the understanding that each month's imprest will be judiciously spent and accounted for in order to qualify for the subsequent month's imprest. Where the MDAs (Agent) act in a manner contrary to laid down rules and procedures, it becomes difficult for them to account for the imprest already received and spent. We are further reminded by the agency theory that the NCRSG (Principal) does not have any foundation for trusting the MDAs (his Agent) since they have different interests and information. Some mitigating measures (budgets and financial regulations) will therefore, be taken by the NCRSG to ensure that the MDAs act according to its documented preferences or to ensure that the scope of the differences and information which exist between the agent and his principal is reduced (Walker, 2003 as cited in Keng'ara [17]). The NCRSG (Principal) ensures that adequate budgetary provisions are made so that the MDAs (Agent) can account for or retire their imprest expenditures. Principal and Agent are therefore, answerable for their conducts and responsibilities (Gray et al, 1987 as cited in Tower [31]). The MDAs (Agent) also ensures that they do not incur illegal expenditures, delegate accountability to those who did not incur the imprest expenditures and fail to account for their imprest expenditures. The NCRSG also ensures that fresh imprest funds are not released to MDAs that have not accounted for the previous imprest they received. Agency theory requires that NCRSG and MDAs prevent the occurrence of unretired imprests by effectively and efficiently tackling the following imprest expenditure management challenges: lack of overhead cost budgetary provisions, off-overhead cost budget expenditures, delegation of retirement of imprest, improper reimbursement and non-retirement of imprests by other heads of departments who collected imprests.

\subsubsection{Stewardship Theory}

This theory rejects the claim made by most corporate governance theories that individuals entrusted with resources and responsibility work for self-interest. A good steward therefore, is a person who is motivated not by self-interest but, by what his master wants him to achieve and be responsible for. This theory sees managers as stewards who align their motives with the goals of their principals. Stewardship theory is therefore, directly related to the agency theory. The stewardship theory is relevant to the current study because the MDA officials when entrusted with the imprest funds are expected to shun personal interest and ensure that they request, spend and retire the imprest in accordance with existing government financial regulations and budgetary provisions.

\subsubsection{Accountability Theory}

Accountability was implied in the agency and stewardship theories already discussed. The agent was seen as being accountable or answerable to his principal for any action taken on his behalf. Accountability theory requires that evidence be provided for the use of resources entrusted in one's care and for compliance with pre-set standards or rules. (Adegite, 2010 as cited in Onuorah \& Appah [24]). The current research is therefore, anchored on financial accountability which Onuorah \& Appah [24] described as the obligation to report that the resources entrusted in your 
care and use have been expended on the intended purpose and all the necessary rules of expenditure have been complied with. All the MDAs must account for the imprest funds collected from the State Accountant-General to render government recurrent services. Financial accountability requires that unretired imprest must not be allowed to occur. This can only be made possible when those actions which give rise to the occurrence of unretired imprests are avoided.

\subsubsection{The Fraud Triangle Theory}

This theory was developed by Donald Cressey, an American Criminologist in 1953 to explain the factors that can possibly lead to fraud and other unethical behaviour. [19]. This theory states that fraud is influenced by three factors namely, pressure (financial or emotional force), opportunity (ability to execute plan without being caught) and rationalization (personal justification of dishonest actions). Therefore, fraud can be prevented by organizations by relieving pressure, minimizing the opportunity to commit fraud and by targeting rationalization which tries to justify the fraud [11]. This theory is relevant to the current study because unretired imprests (current study dependent variable) which by all standards constitute financial fraud, can be caused by opportunity related factors like lack of budgetary provisions, improper reimbursement and off-budget expenditures (current study independent variables). Unretired imprests can also be caused by pressure and rationalization related factors like delegation of retirement of imprest and non-retirement of imprest by other heads of departments (current study independent variables). Therefore, all the conceptual variables of the current study fall within the theoretical framework of the fraud triangle.

\subsection{Review of Related Literature}

Fraudulent practices seem to have contributed significantly to poor financial accountability. Studies conducted by Okpala [23], Aruwa [8] and Umunnah [30] revealed that factors which eroded financial accountability were lack of transparency, unmerited contract awards and poor debt managements that usually lead to questionable loan repayment. Moyo and Taiwo [21] attributed poor financial accountability to the fact that federal allocations were used to settle political kingmakers while councilmen were loyal only to political parties instead of being loyal to those who elected them. Moyo et al [21] also attributed financial accountability problem to non-disclosure of budget allocations and their uses.

Not even the existence of rules can check these fraudulent practices. Regarding the reasons why poor financial accountability thrives in Nigeria, it seems that the existence of legal backing and accounting rules (constitutional provisions and financial regulations, internal control procedures, accounting standards and international code of best practices) has not produced the desired financial discipline. Governance strategies have failed to design a fraudulent-proof system [21].
According to Okpala [23] Nigeria does not lack legal backing and rules for all her financial transactions. Okaro (2004) as cited in Okpala [23] observed that inefficient management of public funds in Nigeria is not caused by lack of enough legal instruments and rules but, by poor financial management culture. Observance of rules and regulations is therefore, better than their existence.

Observance of accounting rules and regulations begins with effective financial reporting, effective public sector audit and effective oversight functions by public accounts committee (PAC). Financial reporting is the best index for measuring the level of financial accountability [8]. Public funds cannot be accounted for because of weak internal control system and poor quality and non-comparability of financial information reported by central government entities $[10,12,26,23]$. Osishami (1992) as cited in Okpala [23] reported that even though the 1999 constitution of Nigeria stipulates that the financial statement should be submitted by the Accountant-General to the Auditor-General within 7 months after financial year end, this provision has been grossly violated due mainly to poor quality accounting system and personnel. In Osun State, Nigeria, Salawu and Agbeja, [25] observed that audit procedures and accountability were ineffective due to political interference and poor quality audit staff. Sikika [27] reported that in Tanzania, the whole process of auditing and parliamentary review failed to create the intended financial discipline, integrity and accountability since the Controller and Auditor-General (CAG) keeps giving similar recommendations each year which the senior management of Ministry of Health and Social Welfare refused to implement.

Still on the failure of public sector audit, Okaro and Okafor [22] reported that poor financial accountability strived because the supreme audit institution is affected by lack of independence, poor accounting environment, lack of executive capacity and poor use of technology. On legislative oversight functions, Randle (2003) as cited in Okpala [23] attributed the failure of PAC (Public Accounts Committee) to lack of skilful, knowledgeable and experience personnel, late finalization of Auditor-General report and failure of MDAs (Ministries, Departments and Agencies) to respond to audit queries. Financial reporting practices, the supreme audit institution and oversight functions have therefore, not been effective in improving the management of public funds.

Financial reporting, audit institutions and oversight functions failed because of lack of compliance with laid down rules. Compliance with accountability tools is very necessary if financial accountability must be effective. Babatunde [10] reported that public sector failures were partly due to non-adherence to principles of internal control. Adeyemi (2005) as cited in Kasum [16] studied 96 Nigerian companies on the impact of accounting standards on financial reporting (accountability index) and reported a reasonable level of compliance but, it was less than the international benchmark of $91 \%$. He also discovered 
variations in the depth of disclosures by the studied companies. The study carried out by Wallace (1988) as cited in kasum [16]) on disclosure practice showed that disclosure levels of Nigerian companies were associated with company size, ownership structure, company age, multinational affiliations, auditors' size, number of employees, stock exchange listing and profitability. In the study of 25 sampled Nigerian quoted companies, gap exists between disclosure standards and disclosure practices. (Kantadu, 2006 as cited in Kasum [16]). Therefore, level of compliance with accountability tools was below the international benchmark and this has contributed to poor financial accountability.

Non-compliance with accountability tools thrive because of weak enforcement of compliance. Moyo and Taiwo [21] discovered that the constitution of the Federal Republic of Nigeria does not entrust the citizens with the power to recall non-performing elected government officials. Companies that failed to comply preferred to pay the penalty for non-compliance since this is cheaper than compliance (Oghuma and Iyoha, 2006 as cited in Kasum, [16]). Nigerian laws suffer from severe weaknesses in enforcement. These weaknesses have been noted by the World Bank in 2004 when it observed that adjudication of cases in Nigeria courts is slow such that regulators are reluctant to go to court and law enforcement agencies to enforce sanctions [23].

The studies reviewed so far show that poor financial accountability strived because of the existence of the following factors: fraudulent practices, misuse of federal allocations, undue political influence on local government councilmen, ineffective use of legal backing and accounting rules, ineffective financial reporting, failure of the supreme audit institution, inadequacy of legislative oversight functions, low level of compliance, low level of enforcement of compliance and lack of severe penalty for non-compliance. No study has however, been carried out to investigate why an enduring and well documented financial accountability problem like unretired imprests still rear their ugly heads in Nigeria and other African countries' MDAs.

\section{Method}

The target population for the current study was 120 made up of all audit staff and few accounts staff of Cross River State Auditor-General's office and the Auditor-General's office for Local Governments. 89 members of this target population were accessible from which a sample of 73 was drawn. Using the accessible population, Yaro Yamani formula was used to determine the sample size as follows:

$$
n=\frac{N}{1+N(e)^{2}}
$$

Where $\mathrm{n}=$ sample size, $\mathrm{N}=$ Population and $\mathrm{e}=$ level of significance or error limit. Substituting the accessible population size of 89 and significance level of 0.05 into the above formula, we have:

$$
\begin{gathered}
n=\frac{89}{1+89(0.05)^{2}} \\
=\mathrm{n}\left(1+89(0.05)^{2}\right)=89 \\
=\mathrm{n}(1+0.2225)=89 \\
=\mathrm{n}(1.2225)=89 \\
=1.2225 \mathrm{n}=89 \\
\mathrm{n}=\frac{89}{1.2225}=72.8=73 \text { approx. }
\end{gathered}
$$

The ex-post facto design and case study approach were adopted for the current study. What informed the choice of the case study approach was the constraint posed by time and cost and because of the inability of the researcher to manipulate the independent variables, the ex-post facto design was adopted. The five independent variables which the study generated had already exerted their influences on the dependent variable before the researcher got there [18]. These independent variables were: lack of budgetary provisions, off-budget expenditures, delegation of retirement of imprest, improper reimbursement and non-retirement of imprest by other heads of departments. The dependent variable was: occurrence of unretired imprests. Using a random sampling technique, a sample of 73 members were selected from the accessible population and they all collected a 5-point likert scale questionnaire which contained 16 structured statements. Only 62 of the sample members responded and returned their questionnaires which assisted in collecting the ordinal data.11 questionnaires were therefore, not returned. The ordinal data were converted to interval data since the 16 likert items on the questionnaire generated 6 scales for the aforementioned independent variables and dependent variables respectively. Consequently, the scores of the individual likert type items from each scale, were summed up to derive composite scores for all the six variables. These steps facilitated the application of multiple regression to the analysis of the interval data.

The relationship between the dependent and independent variables is expressed by the following equation:

$$
\text { OUIMP }=f(L O B U P, O B E X P, D R I M P, I M P R R, N R I M P)
$$

The multiple regression model now becomes:

$$
\begin{gathered}
\text { OUIMP }=b_{0}+b_{1} L O B U P+b_{2} \text { OBEXP }+b_{3} D R I M P \\
+b_{4} I M P R R+b_{5} N R I M P+e_{i}
\end{gathered}
$$

where,

OUIMP $=$ Occurrence of unretired imprests

LOBUP $=$ Lack of budgetary provisions

OBEXP $=$ Off-budget expenditures

DRIMP $=$ Delegation of retirement of imprest

IMPRR $=$ Improper reimbursement

NRIMP $=$ Non-retirement of imprest by other heads of departments

$b_{0}=$ the expected value (constant or intercept) of the dependent variable (OUIMP) when the independent 
variables equal to zero.

$b_{1}-b_{5}=$ Coefficients of the contributions of the independent variables: lack of budgetary provisions, off-budget expenditures, delegation of retirement of imprest, improper reimbursement and non-retirement of imprest by other heads of departments to the occurrence of unretired imprests (OUIMP).

$$
\begin{gathered}
\mathrm{e}_{\mathrm{i}}=\text { error term } \\
b_{0}, b_{1}, b_{2}, b_{3}, b_{4}, b_{5}, \geq 0
\end{gathered}
$$

\section{Results}

\subsection{Demographic and Career Status of Sample Members}

The results show the demographic and career status of sample members in table 3.62 out of a sample of 73 members participated and responded to the 16 likert type items in the structured questionnaire. The response rates for males and females respondents were $86 \%$ and $82 \%$ respectively (see table 4). 44 males and 18 females representing $71 \%$ and $29 \%$ respectively filled in and returned their questionnaires. This male dominance of the state and local government audit offices helped in making the females to become desirous in establishing their presence and this facilitated the easy collection of the required data.27, 31 and 4 respondents representing $44 \%, 50 \%$ and $4 \%$ respectively all filled and returned their questionnaires and they were in the age-brackets of 30-40, 41-51 and 52-62 respectively. This presupposes that all the respondents were knowledgeable and experienced. 57 audit staff and 5 accounting staff representing $92 \%$ and $8 \%$ respectively participated in the survey and the dominance of audit staff was necessitated by the need to collect the right information for the research. The 62 participants were therefore, people who understood the information content of the questionnaire very well.

\section{Regression Analysis (See Table 5)}

The joint contribution of the five predictor variables was moderate and the linear relationship among the variables was significant $\left(\mathrm{R}^{2}=.583, \mathrm{~F}(5,56)=15.629, \mathrm{p}<.01\right)$. The constant or intercept (expected value) of the dependent variable was positive when the independent variables equal to zero and this was also significant $\left(\beta_{0}=5.657, P<.01\right)$.

\section{Hypotheses Testing (See Regression Output Table 5)}

The test results of the five null hypotheses stated in section are as follows:

Hypothesis 1: There is no significant relationship between lack of budgetary provisions and occurrence of unretired imprests in Cross River State MDAs. The regression results showed a weak positive correlation coefficient and this was significant $\left(\beta_{1}=.25, P<.05\right)$. The alternative hypothesis was therefore, accepted while the null hypothesis was rejected.
Hypothesis 2: There is no significant relationship between off-budget expenditures and occurrence of unretired imprests in Cross River State MDAs. The regression results showed a negligible negative correlation coefficient and this was not significant $\left(\beta_{2}=-.01, n . s\right)$. Therefore, the null hypothesis was accepted while the alternative was rejected.

Hypothesis 3: There is no significant relationship between delegation of retirement of imprest and occurrence of unretired imprests in Cross River State MDAs. The regression results showed a weak positive correlation coefficient and this was not significant relative to the alpha level of $.05\left(\beta_{3}=.32, n\right.$.s $)$. It was only approaching significance since its par value was less than .10 (i.e. .071).The null hypothesis was therefore, rejected while the alternative was accepted.

Hypothesis 4: There is no significant relationship between improper reimbursement and occurrence of unretired imprests in Cross River State MDAs. The regression results showed a moderate positive correlation coefficient and this was significant $\left(\beta_{4}=.47, P<.01\right)$. (.50 approx. $)$. The alternative hypothesis was therefore, accepted while the null hypothesis was rejected.

Hypothesis 5: There is no significant relationship between non-retirement of imprest by other heads of departments and occurrence of unretired imprests in Cross River State MDAs. The regression results showed a negligible positive correlation coefficient and this was not significant $\left(\beta_{5}=\right.$ $.078, n . s)$. The alternative hypothesis was therefore, rejected while the null hypothesis was accepted.

\section{Discussion}

The total variability of the criterion variable (occurrence of unretired imprests) as explained by the predictor variables is indicated by an adjusted $\mathrm{R}$ square of .545 or .55 approximately. (see table 5). The model was significant with an F- statistic of 15.629 at the alpha level of .01(i.e. .000). Therefore, the model is highly significant with a moderate explanatory power. This discovery therefore, forms the basis for the analysis of each of the following hypotheses using the regression output on table 4 .

\section{Hypothesis 1}

There is a positive relationship between lack of budgetary provisions and occurrence of unretired imprests. But, this relationship is weak and significant. $\left(\beta_{1}=.25, P<.05\right)$. The meaning of this for the unstandardized coefficient of .254 is that if the lack in budgetary provisions increases by $\$ 1$, unretired imprests in Cross River State MDAs will increase by $\$ 254$, holding the other variables constant. With a standardized coefficient of .305, it means that if the lack in budgetary provisions increases by 1 standard deviation, unretired imprests in Cross River State MDAs will increase by .305 standard deviation holding the other variables constant. At a t-test statistic of 2.499 , this positive 
relationship was significant at the alpha level of .05 (i.e. .015). This weak positive relationship is significant suggesting that lack of budgetary provisions can be used to predict the occurrence of unretired imprests in Cross River State MDAs. Therefore, lack of budgetary provisions increases unretired imprests. Where departmental votes are exhausted and are not augmented before year end, there will be no votes with which to charge all outstanding retirement vouchers and consequently, unretired imprests will occur. Retirement vouchers cannot be accepted and approved by the State Accountant-General unless such vouchers have been duly classified to an approved and existing vote in the departmental vote book. This is therefore, a contribution to the existing literatures on financial accountability studies.

\section{Hypothesis 2}

There is a negative relationship between off-budget expenditures and occurrence of unretired imprests in Cross River State MDAs. This negative relationship is negligible and not significant $\left(\beta_{2}=-.01, n . s\right)$. The meaning of this for an unstandardized coefficient of -.012 is that if off-budget expenditure increases by $\$ 1$ unretired imprests will decrease by $\$ 0.01$., holding the other variables constant. For an standardized coefficient of -.013 , it means that if off-budget expenditures increases by 1 standard deviation, unretired imprests will decrease by -.013 standard deviation holding the other variables constant. At a t-test statistic of -.103, this negative relationship was not significant at the alpha level of .05 (i.e. .918). Off-budget expenditures was not significant and this suggest that it does not have any predictive ability i.e unretired imprests are not sensitive to changes in off-budget expenditures. Off-budget expenditures was therefore, not responsible for the occurrence of unretired imprests in Cross River State MDAs. This finding is not consistent with the works of Moyo and Taiwo [21] which attributed poor financial accountability to the use of federal allocations to settle political kingmakers. The contribution of the current study to the extant literature is that even though misuse of federal allocations had strong association with poor financial accountability in government MDAs, off-budget expenditures have negligible or no association with unretired imprests in Cross River State MDAs. We can however, further verify this inconsistency by extending the current research to other government MDAs in Nigeria.

\section{Hypothesis 3}

There is a positive relationship between delegation of retirement of imprest and occurrence of unretired imprests in Cross River State MDAs. This positive relationship is weak andnot significant. $\left(\beta_{3}=.32, n\right.$.s $)$. The meaning of this relationship for the unstandardized coefficient of .316 is that if the frequency in the delegation of imprest retirement increases by 1 unit, unretired imprests will increase by $\$ 316$, holding the other variables constant. For a standardized coefficient of .237, it means that an increase in the frequency of imprest delegation by 1 standard deviation, will lead to an increase in unretired imprests by .237 standard deviation, holding the other variables constant. At a t-test statistic of 1.841 , this positive relationship was not significant at the alpha level of .05 (i.e. .071). It was only approaching significance thus suggesting a $93 \%$ confidence level for the existence of this relationship. We can therefore, conclude that delegation of imprest retirement has a predictive ability i.e. unretired imprests are sensitive to delegation of retirement of imprests. Therefore, delegation of retirement of imprests was partly responsible for the occurrence of unretired imprests in Cross River State MDAs. Delegation of financial accountability to a public officer who did not incur the public expenditure is a fraudulent practice. This discovery is consistent with the studies conducted by Okpala [23], Aruwa [8] and Umunnah [30] who all attributed poor financial accountability in government MDAs to fraudulent practices.

\section{Hypothesis 4}

There is a positive relationship between improper reimbursement and occurrence of unretired imprests in Cross River State MDAs. This relationship is moderate i.e. .50 approximately (.474) and it is significant. $\left(\beta_{4}=.47, P<\right.$ $.05)$. The meaning of this relationship for the unstandardized coefficient of .474 is that if improper reimbursement increases by $\$ 1$, unretired imprests will increase by $\$ 474$, holding the other variables constant. For a standardized coefficient of .348, it means that if improper reimbursement increases by 1 standard deviation, unretired imprests will increase by .348 standard deviation, holding the other variables constant. At a t-test statistic of 2.914 , this positive relationship was significant at the alpha level of .01 (i.e. .005). Improper reimbursement therefore, was significant suggesting that it has a predictive ability i.e. occurrence of unretired imprests is sensitive to improper reimbursement. Therefore, improper reimbursement was partly responsible for the occurrence of unretired imprests in Cross River State MDAs. Releasing funds to MDAs when the previous amount collected has not been accounted for is also a fraudulent practice. This finding is also consistent with the studies conducted by Okpala [23], Aruwa [8] and Umunnah [30] as already cited in hypothesis 3 above.

\section{Hypothesis 5}

There is a positive relationship between non-retirement of imprests by other heads of departments and occurrence of unretired imprests in Cross River State MDAs. This positive relationship is negligible and it is not significant at a t-test statistic of .383 and at an alpha level of above .05 (.703) $\left(\beta_{5}=.08, n . s\right)$. The meaning of this negligible positive relationship for the unstandardized coefficient of .078 and standardized coefficient of .045 is that this independent variable tagged' non-retirement of imprest by other heads of departments' does not have any predictive 
ability and since its coefficient is moving towards zero, this also suggests that there is no relationship between it and the occurrence of unretired imprests in Cross River State MDAs. Non-retirement of HODs imprest is therefore, not a reason why unretired imprests occurred in Cross River State MDAs. Refusing to account for an expended public fund is a fraudulent practice. This finding is also not consistent with the studies conducted by Okpala [23], Aruwa [8] and Umunnah [30]. The contribution of the current research to existing literature is that non-retirement of imprests by other heads of departments does not have any association with the occurrence of unretired imprests in Cross River State MDAs., even though fraudulent practices were found to be partly responsible for poor financial accountability in government MDAs. This inconsistency should also be verified by extending the current research to other government MDAs in Nigeria.

\section{Summary, Conclusions and Recommendations}

Unretired imprests occur annually in Cross River State MDAs and other African government MDAs. Imprests are not usually accounted for annually partly because of lack of budgetary provisions, fraudulent delegation of accountability over the imprest funds and approving reimbursement of imprests when most of the MDAs have not accounted for the previous imprests they collected. Off-budget expenditures and heads of departments' failure to account for imprests were not associated with the annual

occurrence of unretired imprests in government MDAs. Overhead cost budgets of the MDAs should therefore, be regularly revised while MDA officials who fraudulently delegate imprest retirement and engage in improper imprests reimbursement with treasury officials should be made to face appropriate sanctions.

\section{Direction for Future Research}

The scope of the current study did not permit the inclusion of private institutions. The determinants of unretired imprests (imprest funds not accounted for) were therefore, restricted to only public institutions. This restriction therefore, suggests that further research be extended to private institutions in the form of a comparative study between public and private institutions' accountability determinants. This approach will further verify the inconsistencies between current and previous findings in this research area.

\section{Acknowledgements}

I wish to acknowledge all the staff of State and Local government Auditor-General offices in Cross River State who participated in the study. I am deeply grateful to all those who provided useful research materials.

\section{Appendix}

Table 1. Unretired Imprests of Cross River State Ministries, Departments and Agencies (MDAs)

\begin{tabular}{|c|c|c|c|}
\hline YEAR & AMOUNT & PERCENTAGE & REMARKS \\
\hline & $\mathrm{N}$ & $\%$ & \\
\hline 2009 & $51,786,240.00$ & 3 & Outstanding Audit issues from 2003-2006 b/f \\
\hline 2010 & $919,208,884.00$ & 54 & \\
\hline 2011 & $273,458,286.55$ & 7 & \\
\hline 2012 & $112,870,949.48$ & 21 & \\
\hline 2013 & $356,045,117.28$ & $\mathbf{1 0 0}$ & \\
\hline & $\mathbf{1 , 7 1 3 , 3 6 9 , 4 7 7 . 3 1}$ & & \\
\hline
\end{tabular}

Source: Cross River State of Nigeria Auditor-General Reports 
Table 2. Distribution of Likert Composite Scores of the Dependent Andindependent Variables by Participants

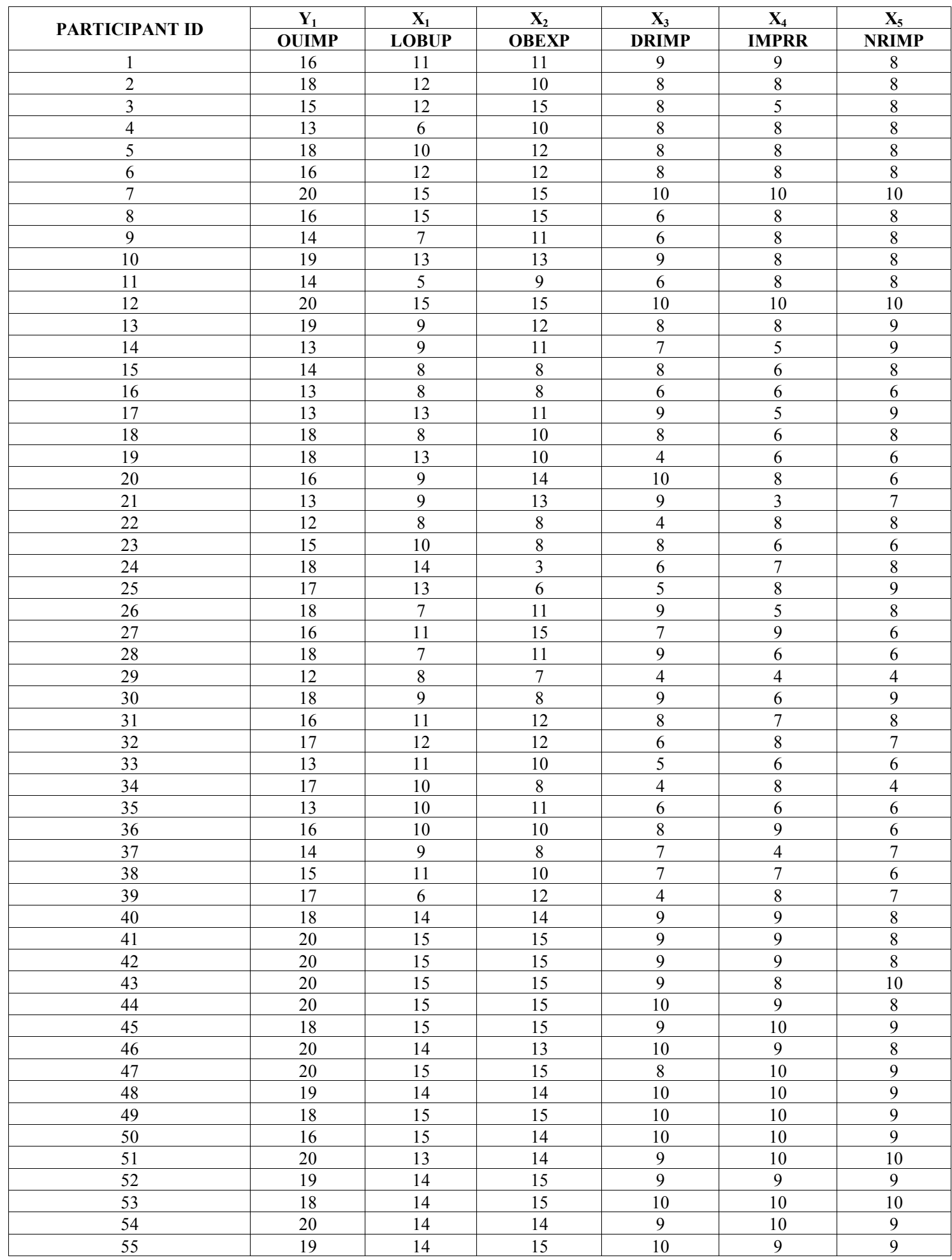

Source: Field Survey

Key:

OUIMP $=$ Occurrence of unretired imprests

LOBUP $=$ Lack of budgetary provisions

OBEXP $=$ Off-budget expenditures

$\mathrm{DRIMP}=$ Delegation of retirement of imprest

IMPRR $=$ Improper reimbursement

NRIMP $=$ Non-retirement of imprest by other heads of department 
Table 3. Population, Sample and Response Rate of Each Group

\begin{tabular}{|c|c|c|c|c|}
\hline GENDER: & POPULATION & SAMPLE & RESPONSE & RESPONSE RATE \\
\hline Male & $70(70 \%)$ & 51 & 44 & $86 \%$ \\
\hline Female & $30(30 \%) \mathbf{1 0 0} \%$ & 22 & 18 & $82 \%$ \\
\hline AGE: & & & & $87 \%$ \\
\hline $30-40$ & $40(40 \%)$ & 31 & 31 & $86 \%$ \\
\hline $41-51$ & $50(50 \%)$ & 36 & 4 & $67 \%$ \\
\hline $52-62$ & $10(10 \%) \mathbf{1 0 0} \%$ & 6 & & $90 \%$ \\
\hline STAFF CADRE: & & & 57 & $50 \%$ \\
\hline Auditing & $80(80 \%)$ & 10 & 5 & $\mathbf{8 5} \%$ \\
\hline Accounting & $20(20 \%) \mathbf{1 0 0} \%$ & $\mathbf{7 3}$ & $\mathbf{6 2}$ & \\
\hline TOTAL: & & & & \\
\hline
\end{tabular}

Table 4. Biographical Data of Respondents

\begin{tabular}{|c|c|c|}
\hline GENDER: & FREQUENCY & PERCENT \\
\hline Male & 44 & $29 \%$ \\
\hline Female & 18 & \\
\hline AGE: & & $44 \%$ \\
\hline $30-40$ & 27 & $50 \%$ \\
\hline $41-51$ & 31 & $6 \%$ \\
\hline $52-62$ & 4 & $92 \%$ \\
\hline STAFF CADRE: & & $8 \%$ \\
\hline Auditing & 57 & \\
\hline Accounting & 5 & \\
\hline
\end{tabular}

Table 5. Regression

Variables Entered/Removed ${ }^{\mathrm{b}}$

\begin{tabular}{|c|l|c|c|}
\hline Model & \multicolumn{1}{|c|}{ Variables Entered } & Variables Removed & Method \\
\hline 1 & $\begin{array}{l}\text { Non-retirement of imprest by other heads of departments, } \\
\text { Off-budget expenditures, Improper reimbursement, Lack of } \\
\text { budgetary provisions, Delegation of retirement of imprest }\end{array}$ & & Enter \\
\hline
\end{tabular}

a. All requested variables entered.

b. Dependent Variable: Occurrence of unretired imprests

\begin{tabular}{|c|c|c|c|c|}
\hline Model Summary \\
\hline Model & $\mathrm{R}$ & R Square & Adjusted R Square & Std. Error of the Estimate \\
\hline 1 & $.763^{\mathrm{a}}$ & .583 & .545 & 1.665 \\
\hline
\end{tabular}

a. Predictors: (Constant), Non-retirement of imprest by other heads of department, Off-budget expenditures, Improper reimbursement, Lack of budgetary provisions, Delegation of retirement of imprest

\begin{tabular}{|c|c|c|c|c|c|c|}
\hline \multicolumn{2}{|c|}{ ANOVA $^{\mathbf{b}}$} \\
\hline \multirow{3}{*}{1} & Sum of Squares & Df & Mean Square & F & Sig. \\
\cline { 2 - 7 } & Regression & 216.668 & 5 & 43.334 & 15.629 & $.000^{\text {a }}$ \\
\cline { 2 - 7 } & Residual & 155.267 & 56 & 2.773 & & \\
\cline { 2 - 7 } & Total & 371.935 & 61 & & & \\
\hline
\end{tabular}

a. Predictors: (Constant), Non-retirement of imprest by other heads of departments, Off-budget expenditures, Improper reimbursement, Lack of budgetary provisions, Delegation of retirement of imprest

b. Dependent Variable: Occurrence of unretired imprests 


\begin{tabular}{|c|c|c|c|c|c|c|}
\hline \multicolumn{7}{|c|}{ Coefficients $^{\mathrm{a}}$} \\
\hline & \multirow[t]{2}{*}{ Model } & \multicolumn{2}{|c|}{ Unstandardized Coefficients } & \multirow{3}{*}{$\begin{array}{c}\begin{array}{c}\text { Standardized } \\
\text { Coefficients }\end{array} \\
\text { Beta } \\
\end{array}$} & \multirow{3}{*}{$\begin{array}{c}\mathrm{t} \\
5.657\end{array}$} & \multirow{3}{*}{$\begin{array}{l}\text { Sig. } \\
.000\end{array}$} \\
\hline & & \multirow{2}{*}{$\frac{\mathrm{B}}{7.257}$} & \multirow{2}{*}{$\begin{array}{c}\text { Std. Error } \\
1.283\end{array}$} & & & \\
\hline \multirow{6}{*}{1} & (Constant) & & & & & \\
\hline & $\begin{array}{l}\text { Lack of } \\
\text { budgetary } \\
\text { provisions }\end{array}$ & .254 & .102 & .305 & 2.499 & .015 \\
\hline & $\begin{array}{l}\text { Off-budget } \\
\text { expenditures }\end{array}$ & -.012 & .113 & -.013 & -.103 & .918 \\
\hline & $\begin{array}{l}\text { Delegation of } \\
\text { retirement of } \\
\text { imprest }\end{array}$ & .316 & .172 & .237 & 1.841 & .071 \\
\hline & $\begin{array}{c}\text { Improper } \\
\text { reimbursement } \\
\end{array}$ & .474 & .163 & .348 & 2.914 & .005 \\
\hline & $\begin{array}{l}\text { Non-retirement of } \\
\text { imprest by other } \\
\text { heads of } \\
\text { departments }\end{array}$ & .078 & .204 & .045 & .383 & .703 \\
\hline
\end{tabular}

a. Dependent Variable: Occurrence of unretired imprests

\section{REFERENCES}

[1] Adeshoba, J. A. Internal audit procedures and operations challenges and initiatives. 2011; Available from http://www.bulletin.oquife.edu.ng/download/11-internal-aud it-procedures-and-operations-challenges.

[2] Amayah, A. F. Evolving accounting procedures for fraud control in the public sector in Nigeria. 2000; Available from http://www.dspace.unijos.edu.ng/bitstream/10485/556/3/Evo lving Accounting

[3] Annual Report and Account. Report of the Auditor-General on the Accounts of the Government of Cross River State for the year ended $31^{\text {st }}$ December, 2009.

[4] Annual Report and Account. Report of the Auditor-General on the Accounts of the Government of Cross River State for the year ended $31^{\text {st }}$ December, 2010.

[5] Annual Report and Account. Report of the Auditor-General on the Accounts of the Government of Cross River State for the year ended $31^{\text {st }}$ December, 2011.

[6] Annual Report and Account. Report of the Auditor-General on the Accounts of the Government of Cross River State for the year ended $31^{\text {st }}$ December, 2012.

[7] Annual Report and Account. Report of the Auditor-General on the Accounts of the Government of Cross River State for the year ended $31^{\text {st }}$ December, 2013.

[8] Aruwa, S. A. S Government financial reporting and public accountability in Nigeria. 2006; Available from http://www.academia.edu/285068/GOVERNMENT_FINAN CIAL_REPORTING_AND_P-73K

[9] Awoyemi, E. O. A guide to government accounting and internal audit, Onibonoje Press, Ibadan Nigeria, 1989.

[10] Babatunde, S. A. Stakeholders' perception on the effectiveness of internal control system on financial accountability in the Nigerian public sector. International
Journal of Business and Management Invention. 2013; 2(1): $16-33$.

[11] Brumell Group The fraud triangle theory. 2015; Available from http://brumellgroup.com/news/the fraud-triangle-theory /

[12] East and Southern African Association of Accountant-General $\{$ ESAAG\}. Guidance on annual government financial reporting for ESAAG member countries. [date unknown]. Available from:http://api.ning.co $\mathrm{m} /$ files/4YilfwQJfCtLQmUE8DEDFmMPY2IBZUghTfNen *MeWjY8Vg7wcO8NfhitpzxdM5gUTJH28-Vtb0SKrVF0H 5-hRwTDU5mJAbs9/1098382945.doc

[13] Federal Republic of Nigeria, Cross River State of Nigeria, Financial Instructions. 1984.

[14] Government to recover unretired imprest from the salaries of Public Officers found guilty. (2012, October 20). Times of Zambia [Internet]. 2012 October 20 [cited 2015 December 15 Available from http://www.lusakatimes. Com/2012/governm ent-recover-unretired-imprest-salaries-public

[15] Inyang, W. S. The impact of overhead cost budgeting on the annual imprest expenditures of State Ministries, Departments and Agencies (MDAs): A study from Cross River State, Nigeria. International Business Research. 2013; 6 (6): 129-142.

[16] Kasum, A. S. The impact of compliance with accounting standards on asset and profitability of Nigerian quoted companies. Journal of Commerce. 2010; 3(3): 57-68.

[17] Keng'ara, R. Effect of funds disbursement procedures on implementation of donor projects in Homabay County, Kenya. Universal Journal of Accounting and Finance. 2014; 2(1): 9-23

[18] Kerlinger, F. N. Foundations of behavioural research. ( $3^{\text {rd }}$ ed.),Harcourt Brace \& Company, Orlando, FL, 1986.

[19] Manurung, D. T. H. \& Hadian, N. (2013). Detection fraud of financial statement with fraud triangle. Proceedings of $23^{\text {rd }}$ International Business Research Conference, Marriott Hotel, Melbourne, Australia. 18-20, November, 2013.

[20] Mbaya, P. Y. \& Namadi, B. Enforcement of public 
accountability in Public Service for sustainable development in Nigeria. Global Journal of Social Sciences. 2004; 3(1\&2): 11-19.

[21] Moyo, N. \& Taiwo, O. Reforms to improve local accountability in Nigeria. 2013 Brookings Blum Roundtable: The Private Sector in then New Global Development Agenda, 2011.

[22] Okaro, S. C. \& Okafor, G. O. The challenges of public sector audit as an effective accountability tool in PPP arrangements in Nigeria. Working Paper Series. 2011.

[23] Okpala, K. E. Fiscal accountability dilemma in Nigeria public sector: A warning model for economic retrogression. Research Journal of Finance and Accounting. 2012; 3(6): 1113-119.

[24] Onuorah, A. C. \& Appah, E. Accountability and public sector financial management in Nigeria. Arabian Journal of Business and Management Review (OMAN Chapter). 2012; 1(6): 1-6.

[25] Salawu, R. O. \& Agbeja, O. Auditing and accountability mechanism in the Public Sector. The International Journal of Applied Economics and Finance. 2007; 1: 45-54.

[26] Sanni, B. W. Impact of financial accountability and transparency of financial reporting in a democratic dispensation. [date unknown]. Available from http://www.unilorin.edu.ng/publications/sannibw/sannijourn al-2.pdf

[27] Sikika Do audit reports effect financial discipline, integrity and accountability?The case of the Tanzanian Ministry of Health and Social Welfare, fiscal year. Briefing Paper. 2011;1-22.

[28] Tanzania Corruption Tracker System. Squandered, unretired TzGovtimprest equals Half national budget (2012). [cited 2012 November 20] Available from http://www.corruptiontr acker.or.tz/dev/index.php?option $=\mathrm{com}=$ content $\&$ task $=$ view \&id=42\&ite...2012

[29] Unretired K445bn imprest shocking. Times of Zambia [Internet]. 2010 March 19. [cited 2015 December 15]. Available from: http://www.lusakatimes.com/2010/03/19/un retired-k445bn-imprest...

[30] Umunnah, C. U. O. Lack of accountants and accountability in Nigeria financial district(s): Is sheer responsibility. 2013; Available from http://.gamji.com/article5000/newS5499.htm

[31] Tower, G. A public accountability model of accounting regulations. British Accounting Review. 1993; 25: 61-85. 